\title{
In Search of the Public Theologian: Mary-Anne Elizabeth Plaatjies-Van Huffel's Womanist Public Engagement
}

\author{
Ashwin Afrikanus Thyssen \\ https://orcid.org/0000-0002-7650-5852 \\ Stellenbosch University \\ ashwinthyssen@gmail.com
}

\author{
Sheurl Davis \\ https://orcid.org/0000-0001-8060-424X \\ Stellenbosch University \\ davissheurl7@gmail.com
}

\section{Abstract}

Academic theology remains male dominated, both in bodies present and in the research methodologies employed. It is a commonplace to refer to Mary-Anne Elizabeth Plaatjies-Van Huffel in terms of a foundationally Reformed theologian and church polity specialist. This is often done without adequate attention to the important role that gender played both in her biography and teaching. There is a need to centre our focus on the matter of gender to see how this had influenced her life's work. The roles fulfilled by Plaatjies-Van Huffel were as an African feminist, decolonial thinker, ecumenist and Reformed theologian. It may be helpful, when considering her life's work, to draw these orientations together through a study of her as a public theologian. An exploration into the contours of her intellectual life may thus be helpful for both understanding the life and work of Plaatjies-Van Huffel, and in analysing the continued development of public theology as an intellectual discipline. Such an analysis, nevertheless, must account for her centring of a particular gender politics in the public sphere as a black woman. Alice Walker offers a definition for "the womanist": "A black feminist or feminist of colour ... Appreciates and prefers women's culture, women's emotional flexibility (values tears as natural counterbalance of laughter), and women's strength ... Committed to survival and wholeness of entire people, male and female." Plaatjies-Van Huffel embodied this definition by working for unity, reconciliation and justice in the three publics. How may a womanist and public theological reading of PlaatjiesVan Huffel enrich our understanding of her? This article employs womanist theory as a lens through which to read and understand Plaatjies-Van Huffel as a public theologian.

\section{UNISA

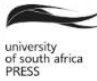


Keywords: Mary-Anne Elizabeth Plaatjies-Van Huffel; womanist theology; Reformed theology; public theology

\section{Introduction}

Public theology exercises a great deal of influence in the South African theological academy. Given this influence and the important role played by Mary-Anne Elizabeth Plaatjies-Van Huffel (1959-2020) in the three publics (aptly captured by David Tracy as church, academy and society) (Tracy 2014), it proves useful to consider the form of her intellectual life within these publics.

There can be no doubt that Plaatjies-Van Huffel, as reverend and professor, impacted the South African community in ways quite profound-not least in the three communities of the church, academy, and broader society. It is for this reason, then, that an investigation into her public role is quite important, not least as part of an effort to memorialise her.

Calling to memory her life and reflecting on the legacy of Plaatjies-Van Huffel, it is incumbent on emerging generations of theologians to pay attention to figures like her. After a brief background of Plaatjies-Van Huffel as a minister and intellectual, this essay attempts to pursue three tasks: first, it discusses womanist theology; second, it offers a reflection on public theology (while affording particular attention to this development in the South African religious imagination); and third, it presents Plaatjies-Van Huffel's scholarship and ministry through the lens of womanist and public theologies. The authors make no attempt to argue that Plaatjies-Van Huffel was a womanist or public theologian; rather, an offer is made to consider her scholarship in the light of these traditions. Doing so, it is believed, presents fresh insight into the dynamic work executed by Plaatjies-Van Huffel in her brief academic career.

\section{The Minister and Intellectual}

Before focusing on the three main probes of this essay, it may first prove enlightening to consider Plaatjies-Van Huffel's biography. Following her death, she has been hailed "the first of firsts" by many-ranging from her denominational home, the Uniting Reformed Church in Southern Africa (URCSA 2020) to the World Council of Churches (WCC 2020a).

The church historian and minister, Charles Flaendorp (2014), penned a rather insightful and integrated essay on the life of Plaatjies-Van Huffel, titled "The Life and Times of Professor Mary-Anne Plaatjies-Van Huffel: A Transformative Church Leader in subSaharan Africa." In rather telling ways, the essay draws together various foci present in Plaatjies-Van Huffel's work. These range from her role as minister and church leader to being an iconic figure in the ecumenical world. 


\section{The Formation of Plaatjies-Van Huffel}

This section notes only major markers that may be considered to have informed her role as a woman and public intellectual. Following her primary and high schooling, in 1978 Plaatjies-Van Huffel set out to pursue a career in education-studying at the University of the Western Cape. Years later, now in 1986, she once again enrolled at the University of the Western Cape, this time pursuing a degree in theology. While studying at the University of the Western Cape, Plaatjies-Van Huffel would then already interrogate the ecclesial imagination (both its limitation and promise) of the Dutch Reformed Mission Church (which would later become the Uniting Reformed Church). It was then she produced her master's dissertation, titled "Is die Kerk Middeleeus? 'n Kritiese Studie oor die Geloofs- en Kerklike Praksis m.b.t. Prostitusie in die NGK Familie in die Kaapse-Skiereiland" (Is the Church Middle-Aged? A Critical Study on the Religious and Ecclesial Praxis with relation to Sex Work in the Dutch Reformed Church Family in the Cape Peninsula) (Plaatjies-Van Huffel 1998). One observes that Plaatjies-Van Huffel was already at work thinking along the lines of women's experiences and gender theory within the church.

Having completed her ministerial training at the University of the Western Cape, as per the requirements of the Curatorium of the Dutch Reformed Mission Church, PlaatjiesVan Huffel was ordained to the Ministry of the Word and Sacrament in 1992, serving two congregations, Robertson and Robertson East. Flaendorp (2014, 54) pointedly remarks: "She served the congregation and the community with distinction from November 1992 until March 2010 for a period of more than 17 years." It may be argued that it was during this time Plaatjies-Van Huffel refined her theological arsenal, by being and becoming an organic intellectual engaged in the challenges of the day for ordinary people.

In 2003 she would graduate with her a doctorate from the University of South Africa; it was titled, "Vroue in die Teologiese Antropologie in die Afrikaanse Gereformeerde Tradisie" (Women in the Theological Anthropology of the Afrikaans Reformed Tradition) (Plaatjies-Van Huffel 2003). Here, more clearly than in her master's dissertation, one notes Plaatjies-Van Huffel's engagement with gender studies - now employing a deconstructivist analysis and offering a critique of the gender politics operational in the Afrikaans Reformed church tradition. Later in 2008, while still a fulltime minister, Plaatjies-Van Huffel graduated with another doctorate, now from the University of Pretoria, titled "Die Doleansie Kerkreg en Kerkregering van die Nederduitse Gereformeerde Sendingkerke en die VGKSA" (The Dissent Church Polity and Governance of the Dutch Reformed Mission Churches and the URCSA) (PlaatjiesVan Huffel 2008).

In 2010, following almost two decades of full-time ministry and part-time study, Plaatjies-Van Huffel was appointed as a lecturer at Stellenbosch University's Faculty of Theology. Shortly after this appointment, in 2012, she would be elected as Moderator of the General Synod by URCSA - again, the first woman to be elected to this senior 
leadership position in the South African Dutch Reformed family. The succeeding year, at the World Council of Churches Conference in Busan, Plaatjies-Van Huffel would be elected as the WCC President for Africa-representing a diverse ecumenical body of no less than 94 denominations (Flaendorp 2014, 57; WCC Africa 2020b).

At the end of 2019, Plaatjies-Van Huffel was appointed full professor in the Department of Systematic Theology and Ecclesiology at Stellenbosch (Spandiel 2020). On 19 May 2020 Plaatjies-Van Huffel died, not having delivered her inaugural lecture. During her tenure, Plaatjies-Van Huffel produced a body of work (edited books, book chapters and journal articles) that concerned topics ranging from religious pluralism, Reformed confessionalism, gender studies, church polity and democratic jurisprudence. This broad disciplinary focus, therefore, suggests that she was quite the versatile and transdisciplinary intellectual.

Reflecting on her being the first of many firsts, the poet Dewald Jacobs (2020), under the pseudonym Digter van Israel, writes: "Onapologeties in versoute Afrikaans / Is Auntie Mary oor haar uitstaande rol in die kerk / Die eerste van die eerste van die eerste / Dit vir ander dra sy die las die seerste." (Unapologetic in refined Afrikaans / Auntie Mary notes her excellent role in the church / The first of the first of the first / It is for others that she carries this weight most painful.) Digter van Israel continues to note the brutality of patriarchy endured by Plaatjies-Van Huffel; which is held to be reflective of so many women who remain the victims and survivors of patriarchy and misogynynot least in church communities.

Following this brief biography, it is clear Plaatjies-Van Huffel played quite an important role as both a woman and public intellectual-first as a minister in a local congregation, then later as a professor in the theological academy. Thus far Plaatjies-Van Huffel's scholarship has only been read with lenses of traditional Reformed and Protestant theologies - but her theology was more nuanced. This, therefore, presents a gap in research concerning her life and scholarship. It is for this reason that an investigation into her life's work may be enriched by reading it through the lenses of womanist and public theologies - and thus also integrating the two traditions. Reading her life's work in this manner would afford us the opportunity to grapple with her unique experience of patriarchy as a woman of firsts.

\section{The Womanist Theorist}

In recent years, much has been written on the tradition of womanist theology and its development, particularly in the United States of America, that is not the focus of this article. However, womanist biblical interpretation of the Bible is not new to the South African academic sphere. Renowned scholars like Sarojini Nadar have explored and embraced this tradition. In her article, A South African Indian Womanist Reading of the character of Ruth (Nadar 2001), she contextualised womanist theology by exploring an alternative portrayal of Ruth for an Indian woman in South Africa. Differently stated, she explores Ruth by utilising the insights of a womanist theological lens. 
Similarly, the focus here is placed on how reading Plaatjies-Van Huffel's intellectual life may be read through the lens of womanist theology. Even so, it is needful to offer a helpful definition that would colour this metaphorical lens. No better definition is found than that provided by Alice Walker in the text In Search of Our Mothers' Gardens, that has been claimed by womanist theologians. Walker, drawing from the cultural riches of black southern America, imaginatively posits:

From womanish. A black feminist or feminist of color ... Committed to survival and wholeness of entire people, male and female ... Loves music. Loves dance. Loves the moon. Loves the Spirit. Loves love and food and roundness. Loves struggle. Loves the Folk. Loves herself. Regardless ... "Womanist is to feminist as purple is to lavender" [emphasis ours]. (Walker 1983, xi-xiii)

We are intentional about noting this expansive and lengthy definition; in doing so, it is contended that the life of Plaatjies-Van Huffel gave faithful expression to this definition. Put differently, in life and work Plaatjies-Van Huffel centred this black feminist ethic which was predicated on love.

The genealogy of womanist theory and theology can be traced back to the 1980s when African-American, or black, women developed a "voice, a self-defined, collective black women's standpoint about black womanhood" (Collins 1996, 9). Since then, black women's voices have been heard in the public, academic and ecclesial spheres in ways unthinkable previously.

Fundamentally, in the face of and amid the brutality of white supremacy and patriarchy, womanist theory-and by extension womanist theology-concerns talking back. Commenting on the importance of this act by womanists, bell hooks $(2015,22)$ states: "To speak then when one was not spoken to was a courageous act - an act of risk and daring." Advancing this very point, hooks claims:

Moving from silence into speech is for the oppressed, the colonized, the exploited, and those who stand and struggle side by side a gesture of defiance that heals, that makes new life and new growth possible. It is that act of speech, of "talking back," that is no mere gesture of empty words, that is the expression of our movement from object to subject — the liberated voice. (hooks 2015, 29)

How, then, does womanist theology talk back? Pioneering womanist theologian, Delores Williams, offers guidance in this regard. For this towering intellectual, womanist theology is informed by four foundational elements: first, multidialogical intent; second, liturgical intent; third, didactic intent; fourth, commitment to reason and the validity of female imagery and language (Williams 1993, 149). Any discussion of womanist theology's methodological and theoretical framework must return to these four elements. 
Why is the notion of "talking back" important? Talking back via this fourfold intent focuses the attention squarely on black women's experiences of gendered and racial oppression. "As womanist theology takes full account of racism, sexism, and classism inherent to mainline Christian theology, it refuses to surrender to an interpretive method that insists on compartmentalizing race, class, gender, and sexuality as separate and even singular concerns in the analysis of Black women's faith" (Floyd-Thomas 2010, 53). Stated differently, Williams's four elements implicitly employs and advances Kimberlé Crenshaw's notion of intersectionality, the recognition of an interlocked system of oppression that affects different sections of the population differently because of their identity markers (Carbado et al. 2013, 304). Crenshaw suggests that black women are differently oppressed when compared to white women and black men; womanist theology, then, focuses precisely on their (black women's) unique experience of oppression.

\section{Using Womanist Theory to Interpret Plaatjies-Van Huffel}

Bearing this discussion of womanist theory in mind, it may be enriching to consider Plaatjies-Van Huffel's life and work through the lens of womanist theology. As previously stated, Plaatjies-Van Huffel did not in her work nor in person use the term "womanist" to identify herself; rather, she consistently employed the term "black feminist." At this point Collins $(1996,15)$ is most helpful, she notes: "No term currently exists that adequately represents the substance of what diverse groups of black women alternately call 'womanism' and 'black feminism'." Furthermore, it is also important to consider the unique context in which Plaatjies-Van Huffel lived and produced her thought - that is, South Africa both before and after the 1994 democratic election. In this context, then, the idea of womanism was not too greatly appropriated by the black women, despite the similarities that probably existed been between South African apartheid and American segregation.

\section{Black and Coloured}

Black and coloured constitute some of the sub-categories that expound Plaatjies-Van Huffel's feminist concerns. Considering Plaatjies-Van Huffel's life and work through the coloured lens of womanist theology offers quite some insight. We may see this in two interesting ways. First, the great body of her work underscores that she was a black feminist; this orientation would be a mainstay in her theological development. This may be observed from her 1998 master's dissertation, titled "Is die Kerk Middeleeus? ' Kritiese Studie oor die Geloofs- en Kerklike Praksis m.b.t. Prostitusie in die NGK Familie in die Kaapse-Skiereiland"; in it one already notes the centring of a black feminist critique of socio-political and ecclesial life. Again, in her doctoral thesis, Plaatjies-Van Huffel would more forthrightly offer renewed black feminist critique; under the title, "Vroue in die Teologiese Antropologie in die Afrikaanse Gereformeerde Tradisie" (Plaatjies-Van Huffel 2003). Now, in this work, her critique was focused on the hegemonically patriarchal South African Afrikaans Reformed tradition and its denominations. It must be stated, this critique was offered at a time when the national 
Reformed community was making sense of its role in the post-1994 democratic order (Vosloo 2013; Weisse and Anthonissen 2004). Most interestingly, this black feminist critique employs the deconstructivism of Foucault; throughout her career, of course, she would return to Foucauldian thought (Plaatjies-Van Huffel 2011). Informed by the insights of womanist theology, these early works by Plaatjies-Van Huffel may be considered to have set the stage for the quality and contours of her intellectual lifefocusing closely on the racialised and gendered nature of oppression. Divorcing Plaatjies-Van Huffel's intellectual work from her black feminist critique, contemporary readers may be tempted to decontextualise these texts and her life wholly; therefore, obfuscating the very locus of her theological engagement. A womanist analysis, then, ensures that the racialised and gendered nature of Plaatjies-Van Huffel's work is taken seriously.

\section{Gender-occasioned Delayed Ordination}

The second way in which a womanist lens enriches a consideration of Plaatjies-Van Huffel, concerns her life. Recounting her lived experience when interviewed in an episode of kykNET's "Diep Spore," Plaatjies-Van Huffel noted the patriarchal context which she had to navigate as black woman called to ministry and within the theological academy. It is this context of Afrikaans Reformed pietistic patriarchy that served as the stage on which she would perform her life, within its confines and limitations. As noted previously, much time had elapsed - a period of 10 years - after she was licensed by the Curatorium of the Dutch Reformed Mission Church before she was ordained to the ministry. Her delay to the ordination was largely due to the denomination's unwillingness to call a woman to ministry. In one of her finally published articles, Plaatjies-Van Huffel (2019b) notes the theological and hermeneutical shifts that were needed within the denomination, but left undone. Offering insightful, compassionate critique, she writes about the Uniting Reformed Church in Southern Africa's gender politics:

URCSA's decisions regarding gender justice during the past 25 years are characterised by ambivalence. On the one hand women have been accepted in leadership roles within URCSA, but on the other hand the role of women has been limited in practice. The dichotomy is embodied in the liturgical forms, church stipulations and regulations, elections, decisions on gender issues, the appointment of delegations, et cetera. We should ask ourselves if URCSA is not reinforcing and promoting deep-seated societal biases and misperceptions about the ability of women to take up leadership roles in church and society. (Plaatjies-Van Huffel 2019b, 19)

Utilising the insights of womanist theology, the life and work of Plaatjies-Van Huffel are put into the context of both racism and sexism, which she sought to do throughout her life. Her appointment as lecturer at Stellenbosch University's Faculty of Theology, then, is the recognition of her stellar academic achievements - holding two doctorates and contributing to the South African ecumenical network. Thus, it is quite unsurprising that she played numerous important roles in the various religious bodies-ranging from 
the South African Council of Churches to the World Council of Churches. Therefore, using womanist theology as a lens to read and understand Plaatjies-Van Huffel's work is most enriching. If anything, it suggests that throughout her life she sought to talk back to the dismissive and death-dealing culture of racialised patriarchy — or what bell hooks terms "imperialist white supremacist capitalist patriarchy." Quite interestingly, when we see Plaatjies-Van Huffel's life and work in this light-as a response to white supremacist patriarchy - we may understand the tenets of womanist theology that much better, and we would recognise how they may have implicitly saturated her thoughts; those are radical subjectivity, traditional communalism, redemptive self-love and critical engagement (Floyd-Thomas 2010, 53-55).

To further employ the insights of womanist theology in the life and being of PlaatjiesVan Huffel, one needs to consider her God experience. Womanist scholars place much emphasis on their experience of God and not what has been forced upon them in church and Christianity. Mitzi Smith frames this as follows:

Womanist biblical scholars understand God and the goodness of God to be situated in black female bodies. And we are determined to shine a light on injustice even, when it is found in the black ink of the sacred text and to declare truths that can lighten and enlighten the paths of the most marginalised. (Smith 2015,112-113)

Anyone who had physical contact with Plaatjies-Van Huffel was exposed to her God experience. Whenever she would part from you, she would send you off with the words: "may the good Lord bless you" (Plaatjies-Van Huffel 2018a). Her God experience, in a sense, is at the heart of this article's focus. Despite the hurtful experiences of white supremacy and patriarchy in the church, she continued to witness to a God who was her good Lord, a good Lord who blesses the marginalised.

\section{The Public Theologian}

It is true that Plaatjies-Van Huffel was as a womanist theologian as we have argued, because of her talking back; yet she may also be considered a public theologian, who navigated the church, academy and society. We now turn our attention to her as a public theologian. There is little doubt that the discipline of public theology is not only gaining all the more traction in Africa, but also cementing itself in the theological academy. This is witnessed nowhere better than in the recent publication of African Public Theology (Agang 2020), edited by Sunday Agang, Jurgen Hendricks and Dion Forster. An investigation into Plaatjies-Van Huffel as a public theologian, is therefore quite timely and rather relevant — especially given the public role she played.

On the international scene, of course, public theology has carved out its niche within the theological academy. As a system of thought, public theology draws much from the insights of the Social Gospel movement (of the nineteenth and twentieth centuries), Catholic social teaching; while also utilising the intellectual insights of Reinhold Niebhur, Dietrich Bonhoeffer, Jürgen Moltmann and Martin Luther King, Jr (Day and 
Kim 2017, 2). At the heart of the intellectual development of public theology-as we know it today (building on the work of Martin Marty and Robert Bellah) - is the Catholic theologian David Tracy's The Analogical Imagination: Christian Theology and the Culture of Pluralism (Tracy 1981). In this stellar text, Tracy sought to interrogate the notions of "public" and the public role of theology. Tracy "contended that theology needs to engage three publics: the church, the academy and society. Rather than only speaking in and for the church in a language understood only within that context and from a perspective of privileged rationality, Tracy argued that theology needs to break out of insularity into true public discourse" (Day and Kim 2017, 3). Public theology, then, engages the three publics on their own respective terms; that is, using the language employed by that particular public.

Considering the paradigmatic nature of public theology, the renowned theologian, Dirkie Smit, calls to memory the important and ground-breaking work of Russel Botman. Already in the 1990s, Botman was concerned about South African religious and political life, and how this impacted the public role of theology (Botman 1993; 2002). Smit notes, for Botman "public theology was not [yet] a paradigm in the singular: a new form of doing theology, a new methodology, describing the state of the art, the rules to be followed, the method to use, the best practices known and available" (Smit 2017, 68). We, therefore, in this essay employ Botman and Smit's understanding of public theology's paradigmatic nature to use it (the discipline) as a hermeneutical lens to read and understand Plaatjies-Van Huffel's life and work.

Taking his cue from Bedford-Strohm, Smit opines the methods presently employed by the scholars of public theology. For these two theologians, and those following them, the paradigm of public theology is underscored by six methodological orientations. First, public theology must display continuity with biblical-theological traditions. "Public theology should be recognizable as theology" (Smit 2017, 71). Second, public theology is multilingual, using a range of distinctive languages. Smit is correct by asserting that public theology is different from church theology; therefore, requiring different languages. Third, following the second, public theology must be knowledgeable. Here Smit $(2017,79)$ offers: "Perhaps this - the need for informed knowledge - is the only real criterion that can be used to describe public theology." This means, public theology must draw, in an integrated fashion, from a multiplicity of disciplines because it attempts to speak to the three publics. Fourth, public theology also seeks to provide a sense of orientation. He further claims that "church and theology is not merely interested in public life for interest's sake, but because it wants to make a difference. Public theology wants to contribute, to help provide perspective, to help suggest ways forward, to help provide direction" (Smit 2017, 82). Fifth, public theology has an inherent prophetic quality; that is, it offers critique and resistance to the systems that cause harm in public life (Smit 2017, 83). Finally, Bedford-Strohm contends that public theology must be inter-contextual; truly, it must assert to be cognisant and conversant with a diversity of contexts (Smit 2017, 71). 
Informed by these foundational aspects of public theology, it may be argued that Plaatjies-Van Huffel's life and work offer an impetus to apply this lens (a public theological reading) to it. This lens takes seriously the methodological orientations outlined. In both life and work she displayed the paradigmatic nature operative in Smit's intellectual imagination, much like that of Botman. Responding to the scourge of gender-based violence, Plaatjies-Van Huffel utilised biblical-theological traditions as a response (Plaatjies-Van Huffel 2019a). As church polity specialist, she sought to bring religious and legal discourses into relation, as such embodying an ethic of multilingualism. Additionally, by using the gifts of social media, Plaatjies-Van Huffel made knowledge that much more accessible. In two articles she grapples with the concerns of inter-contextuality in a rather erudite fashion; these are "A History of Gender Insensitivity in URCSA" (Plaatjies-Van Huffel 2019b) and "Blackness as Ontological Symbol: The Way Forward" (Plaatjies-Van Huffel 2020a). It should be noted that Plaatjies-Van Huffel's public engagement may also be understood in relation to membership in various associations: International Consortium for Law and Religion Studies; Africa Consortium for Law and Religion Studies; and Circle of Concerned African Women Theologians. In these ways, then, Plaatjies-Van Huffel was a public theologian - her life's work was oriented in service of the public good. This may be seen in her work in the church, the academy and society. From her ordination until her death she drew the three publics into conversation, in pursuit of justice.

The field of public theology shows signs of much promise, not least because of BedfordStrohm's six aspects. However, at present it remains dominated by a large contingency of white male thinkers - though, there are some exceptions. Esther McIntosh (2017, 298) remarks, "the very notion of 'public theology' is contentious when considering issues of race, gender and sexual equality and yet these issues are of primary significance for Christian churches today." It is, if we are to take public theology seriously, important to consider the pitfalls of this discipline in relation to gender politics. "Consequently, it seems that public theology, thus far, has failed to properly acknowledge its reliance on a Habermasian notion of the public sphere that is founded on a concept of reason that has excluded women and other marginalized groups" (McIntosh 2017, 303). Perhaps, then, this calls for a re-orientation that does justice the experiences of women, and particularly black women in a context such as South Africa.

Commenting on the Africa we have inherited and maintained, Agang writes:

Almost everyone in Africa acknowledges that we are currently living in an Africa we do not want. It is not that we do not love Africa-we do, passionately and deeply. There is much that is good and beautiful in Africa and much that we can be proud of in our past. But when we look around us, we see abundant evidence that all is not well in Africa. (Agang 2020, 29)

Plaatjies-Van Huffel displayed no romanticised dream of the Africa in which she developed her scholarship. We contend that it was this Africa in which Plaatjies-Van Huffel undertook her ministry and developed her scholarship. If anything, she was 
consistently mindful of the challenges that beset post-independence Africa and the laborious work required to redirect its future (not least as it pertained to religion and culture). Schooled in Foucauldian deconstructivism, Plaatjies-Van Huffel is in agreement with the public theologian, Esther Mombo, who argues:

Sometimes we forget that culture is not static. It changes over time ... Understandably, this change is stressful. For some it represents a step into the unknown, while for others it represents a loss of things to which they felt entitled. This stress explains why some people look for ways to deny female empowerment, claiming that it goes against our culture. But culture cannot be absolutized. We need to recognize that in some respects our traditional culture may have harmed women (and thus also men). Rigid understandings of gender do not allow us to exercise the gifts given to each of us by God. (Mombo 2020, 248)

In this same essay, titled "Gender" published in African Public Theology, Mombo (2020) calls men to account for their commitment to speak to the realities of varied oppressions without considering how this impacts women. Here one may observe a semblance of continuity with the work executed by Plaatjies-Van Huffel, as early as 1998, and sustained throughout her career. This semblance, of course, was PlaatjiesVan Huffel's commitment to uncovering the manifold ways in which culture it not static; rather, culture is constructed.

Perhaps the best definition for the work of public theology in South Africa is that offered by Nico Koopman, a pioneering intellectual on the South African religious landscape. Helpfully, Koopman, in defining public theology states:

Public theology holds on to this twofold focus: on the one hand, the loving God, and on the other hand, the world, the kosmos [cosmos] that is object of this Trinitarian love. Public theology consistently reflects upon the contents and rationality of this love. Public theology faithfully endeavours to reflect upon the exciting implications that this Trinitarian love has for South Africa, the rest of Africa, and the rest of the world with all its joys and sorrows. (Koopman 2010, 138)

It is our contention that Plaatjies-Van Huffel, in both scholarship and ministry, sought to advance this twofold focus (the loving God and the object of this Trinitarian love); however, she did so with a focus on the lived experiences of black women. In "Vroue in die Teologiese Antropologie in die Afrikaanse Gereformeerde Tradisie" (PlaatjiesVan Huffel 2003) she considers the public role that gender constructions play within the Reformed tradition. Thereby, Plaatjies-Van Huffel centred the lived experiences of women.

When discussing public theology, it is needful to consider the methodology employed. Quite helpfully, McIntosh $(2017,318)$ rightly asserts: “A constructive methodology for the future of public theology has to begin by looking at who is included in its canon and where it finds its theology." A public theology-informed reading of Plaatjies-Van 
Huffel's life and work may, in effect, offer the very critique needed for its development in South Africa - which, we contend, may be much to the aid of male theologians who are presently directing its course.

\section{Plaatjies-Van Huffel: Womanist and Public Theologian?}

Thus far we have only insinuated at Plaatjies-Van Huffel's reliance on Foucault. Throughout her body of work (from as early as 2003), one can trace Foucauldian deconstructivism as a golden thread-this is quite pronounced in one of her final publications (Plaatjies-Van Huffel 2019b). As such, it may prove worthwhile in this conclusion to attend to the Foucauldian conception of the intellectual; and how this may inform our reading of Plaatjies-Van Huffel's public engagement (using the lenses of womanist and public theologies).

When asked about the role of the intellectual, Foucault responded quite succinctly: "It is absolutely true that when I write a book I refuse to take a prophetic stance, that is, the one of saying to people: here is what you must do-and also: this is good and this is not" (Hendricks 2000). With these words, Foucault presents a negation of the prophetic role of the intellectual. Put differently, Foucault resists the temptation of acting in the role of a prophet who offers universal claims of truth and justice. Foucault's critique of the intellectual as prophet is possibly "not so much a rejection of prophecy as an exile from it - a distancing without a complete break, a separation just great enough to disturb the role of the intellectual as prophet without the negation that can too easily result in the further reinforcement of this role" (Hendricks 2000). It is this rupture and moment of separation, we maintain, that may offer some impetus for understanding PlaatjiesVan Huffel as an intellectual within her public engagement.

According to Edward Said (1996, 9), Foucault notes that "the so-called universal intellectual has had [their] place taken by the 'specific' intellectual, someone who works inside a discipline but who is able to use [their] expertise anyway." Plaatjies-Van Huffel grounds her intellectual life in her subjectivity (much like womanist theologians), and makes no attempt at universalising her lived experience. By rejecting a framework of normative claims about religion and by prioritising subjectivity (through ethnography), she invites all religious thinkers to mine the riches of deconstructivism.

Understanding Foucault's notion of the intellectual as not fulfilling a prophetic role, one may note some continuity with Antonio Gramsci's conception of the intellectual. He proffers: "All [people] are intellectuals, one could therefore say: but not all [people] have in society the function of intellectuals" (Gramsci 1971, 9). As a Marxist, Gramsci draws a distinction between traditional intellectuals (serving a function as the educated class, usually arbiters of social power) and organic intellectuals (who direct the ideas and aspirations of their class). Expanding Gramsci's distinction between the two groups of intellectuals, Said posits: 
... the intellectual, in my sense of the word, is neither a pacifier nor a consensus-builder, but someone whose whole being is staked on a critical sense, a sense of being unwilling to accept easy formulas, or ready-made clichés, or the smooth, ever-so-accommodating confirmations of what the powerful or conventional have to say, and what they do. Not just passively unwillingly, but actively willing to say so in public. (Said 1996, 8)

Drawing together these insights - of Foucault, Gramsci and Said — one becomes quite aware of the role Plaatjies-Van Huffel played in the public. If anything, she located herself, as pastor and scholar, in the liminal space of Foucault's "exile" while maintaining solidarity with Gramsci's underclass - thus, she may be presented as quite a refined organic intellectual. The justification for Plaatjies-Van Huffel's role as organic intellectual may be observed in her ministry in the URCSA congregations of Robertson and Scottsdene as well as her professoriate at Stellenbosch University; this, if anything, was most clearly distilled in her public persona through her Facebook account (PlaatjiesVan Huffel 2020b). It was on these platforms that she displayed tremendous insight as organic intellectual; implicitly merging the traditions of womanist and public theology.

Throughout this essay, attempts have been made to highlight what promise a womanist and public theological reading may offer our consideration of Plaatjies-Van Huffel. We have maintained that she did not identify with these disciplines to advance their cause. However, upon closer investigation, one may note that her public engagement was grounded in the methodological and epistemological contours of both the traditions of womanist and public theologies. Even so, Plaatjies-Van Huffel's views must be understood to be founded on the discursive cornerstone of Foucauldian deconstructivism; failure to do so obfuscates its actual focus.

The term "womanist" was coined by Alice Walker; thus, it does us well to return to her writing and have that inform our understanding of womanist theory. In the essay titled, "In Search of Our Mothers' Gardens" Alice Walker writes lyrically:

And so our mothers and grandmothers have, more often than not anonymously, handed on the creative spark, the seed of the flower they themselves never hoped to see: or like a sealed letter they could not plainly read ... Guided by my heritage of a love of beauty and a respect for strength — in search of my mother's garden, I have found my own. (Walker 1993, 344)

In her own right, Plaatjies-Van Huffel exposed the lies at the heart of patriarchal religion and society. In ways quite profound, she implicitly merged the insights of womanist and public theologies, giving expression to them within the South African context. In this sense, then, Plaatjies-Van Huffel was a brilliant public intellectual.

It is our contention that the disciplines of womanist and public theologies will be greatly enriched by a continued return to the pioneering work of Plaatjies-Van Huffel. In both life and scholarship Plaatjies-Van Huffel enacted the "talk back" foundational in womanist theology; thereby asserting herself as radical subject within the white 
supremacist patriarchal maelstrom. Further, throughout her career, Plaatjies-Van Huffel showed herself well-versed in the languages employed in the three publics; as such she resembled the paradigm conceptualised by Bedford-Strohm.

\section{Conclusion}

In the South African theological academy, we observe a growing contingent of theologians who identify themselves as public and womanist theologians. It is for this reason that a study of Plaatjies-Van Huffel's public engagement is timely and important. In this article the two traditions of womanist and public theologies were brought into dialogue; they were used as hermeneutical lenses through which to read the life and teaching of Plaatjies-Van Huffel. We argued that she was a womanist theologian because she employed an ethic of "talk-back," which is foundational in womanist theory. Furthermore, not only was Plaatjies-Van Huffel in conversation with the three publics; the six methodological orientations of public theology pervade her thought. As such, we argue that she was a public theologian. Finally, we argue that Plaatjies-Van Huffel may rightly be considered an organic intellectual, who conceived of life in the liminal space of the "exile."

Plaatjies-Van Huffel (2018b) once remarked that the hymn, "The Church's One Foundation" had lingered in her ears. In both life and teaching she loved the church most dearly, displaying an intense desire to see it play its prophetic role in the publicresisting the powers of white supremacist patriarchy. This article, therefore, contributes to the body of literature on clergywomen who have and are leading the South African ecumenical church. It does so intentionally by drawing from the traditions of womanist and public theologies, that are garnering all the support in the theological academy. Any ecclesiological study going forward must grapple with the manifold ways in which patriarchy continues to stifle the ecumenical church, particularly in South Africa. In both life and teaching, Plaatjies-Van Huffel shed light on the difficult work that is to be done.

\section{References}

Agang, Sunday B. 2020. "The Need for Public Theology in Africa." In African Public Theology, edited by Sunday B. Agang, H. Jurgens Hendricks, and Dion A. Forster. Bukuru: HippoBooks. Kindle.

Botman, H. Russel. 1993. "Discipleship as Transformation? Towards a Theology of Transformation." PhD thesis. University of the Western Cape.

Botman, H. Russel. 2002. "Theology after Apartheid: Paradigms and Progress in South African Public Theologies." In Theology in the Service of the Church, edited by Wallace M. Alston, 36-52. Grand Rapids: Eerdmans. 
Carbado, Devon W., Crenshaw, Kimberlé W., Mays, Vickie M., and Tomlinson, Barbara. 2013. "Intersectionality: Mapping the Movement of a Theory." Du Bois Review: Social Science Research on Race 10 (2): 303-312. https://doi.org/10.1017/S1742058X13000349.

Collins, Patricia Hill. 1996. "What's in a Name? Womanism, Black Feminism, and Beyond." The Black Scholar 26, no. 1 (Winter/Spring): 9-17. https://doi.org/10.1080/00064246.1996.11430765.

Day, Katie, and Kim, Sebastian. 2017. "Introduction.” In A Companion to Public Theology, edited by Sebastian Kim and Katie Day, 67-92. Leiden: Koninklijke Brill.

Flaendorp, Charles. 2014. "The Life and Times of Professor Mary-Anne Plaatjies-Van Huffel: A Transformative Church Leader in sub-Saharan Africa.” Studia Historiae Ecclesiasticae 40: 53-63.

Floyd-Thomas, Stacey M. 2010. "Womanist Theology." In Liberation Theologies in the United States: An Introduction, edited by Stacey M. Floyd-Thomas and Anthony B. Pinn, 37-60. New York: New York University Press.

Gramsci, Antonio., Hoare, Quintin., and Smith, Geoffrey Nowell. 1971. Selections from the Prison Notebooks of Antonio Gramsci. New York: International Publishers.

Hendricks, Christina. 2000. "Foucault's Prophecy: The Intellectual as Exile.” PhilArchive. Accessed July 29, 2020. https://philarchive.org/rec/HENFP.

hooks, bell. 2015. Talking Black: Thinking Feminist, Thinking Black. New York: Routledge. https://doi.org/10.4324/9781315743134.

Jacobs, Dewald. 2020. "Prof Mary-Anne Plaatjies-Van Huffel.” Accessed July 29, 2020. https://www.facebook.com/photo.php?fbid=3957678310939988\&set=pb. 10000093573448 9.-2207520000.\&type $=3$.

Koopman, Nico. 2010. "Some Contours for Public Theology in South Africa." International Journal for Public Theology 14: 123-138. https://doi.org/10.1515/ijpt.2010.9.

McIntosh, Esther. 2017. “'I Met God, She's Black': Racial, Gender and Sexual Equalities in Public Theology." In A Companion to Public Theology, edited by Sebastian Kim and Katie Day, 298-324. Leiden: Koninklijke Brill. https://doi.org/10.1163/9789004336063_015.

Mombo, Esther. 2020. “Gender.” In African Public Theology, edited by Sunday B. Agang, H. Jurgens Hendricks, and Dion A. Forster. Bukuru: HippoBooks. Kindle.

Nadar, Sarojini. 2001. "A South African Indian Womanist Reading of the Character of Ruth." In Other Ways of Reading: African Women and the Bible, edited by Musa W. Dube, 1711. Atlanta: Society of Biblical Literature. 
Plaatjies-Van Huffel, Mary-Anne E. 1998. "Is die Kerk Middeleeus? 'n Kritiese Studie oor die Geloofs- en Kerklike Praksis m.b.t. Prostitusie in die NGK Familie in die KaapseSkiereiland." MTh dissertation. University of the Western Cape.

Plaatjies-Van Huffel, Mary-Anne E. 2003. "Vroue in die Teologiese Antropologie in die Afrikaanse Gereformeerde Tradisie." PhD thesis. University of South Africa.

Plaatjies-Van Huffel, Mary-Anne E. 2008. "Die Doleansie Kerkreg en Kerkregering van die Nederduitse Gereformeerde Sendingkerke en die VGKSA." PhD thesis. University of Pretoria.

Plaatjies-Van Huffel, Mary-Anne E. 2011. "Patriarchy as Empire: A Theological Reflection." Studia Historiae Ecclesiasticae 37, (December): 259-270.

Plaatjies-Van Huffel, Mary-Anne E. 2018a. "Merry Christmas Family.” Accessed September 28, 2020. https://www.facebook.com/ma.vanhuffel/posts/10216225060891190.

Plaatjies-Van Huffel, Mary-Anne E. 2018b. “The Hymn 'The Church's One Foundation' is Lingering in my Ears.” Accessed September 28, 2020. https://www.facebook.com/ma.vanhuffel/posts/10214958270062211.

Plaatjies-Van Huffel, Mary-Anne E. 2019a. "The Rape of Tamar: Silence on Gender-based Violence." Accessed September 28, 2020. https://www.facebook.com/ma.vanhuffel/posts/10218048985928176.

Plaatjies-Van Huffel, Mary-Anne E. 2019b. "A History of Gender Insensitivity in URCSA." Studia Historiae Ecclesiasticae 45 (3): 1-22.

Plaatjies-Van Huffel, Mary-Anne E. 2020a. "Blackness as Ontological Symbol: The Way Forward." Review and Expositor 117 (1): 101-113. https://doi.org/10.1177/0034637320904718.

Plaatjies-Van Huffel, Mary-Anne E. 2020b. “Ma Plaatjies-Van Huffel.” Accessed July 29, 2020. https://www.facebook.com/ma.vanhuffel.

Said, Edward W. 1996. Representations of the Intellectual: The 1993 Reith Lectures. New York: Vintage Books.

Smit, Dirk J. 2017. "Does it Matter? On Whether there is Method in the Madness." In $A$ Companion to Public Theology, edited by Sebastian Kim and Katie Day, 67-92. Leiden: Koninklijke Brill. https://doi.org/10.1163/9789004336063_005.

Smith, Mitzi J. 2015. I Found God in Me: A Womanist Biblical Hermeneutics Reader. Eugene: Wipf and Stock.

Spandiel, O. 2020. "SU Theological Prof Remembered for her Legacy." Matie Media, May 23, 2020. https://www.matiemedia.org/su-theological-prof-remembered-for-her-legacy/. 
Tracy, David. 1981. The Analogical Imagination: Christian Theology and the Culture of Pluralism. New York: Crossroad. https://doi.org/10.1017/S0360966900018983.

Tracy, David. 2014. "Three Kinds of Publicness in Public Theology.” International Journal of Public Theology 8: 330-334. https://doi.org/10.1163/15697320-12341354.

URCSA Cape. 2020. "URCSA Mourns the Passing of Rev. Prof. Mary-Anne Plaatjies-Van Huffel." Accessed July 29, 2020. https://www.facebook.com/URCSACAPE/posts/708225349936454.

Vosloo, Robert R. 2013. "Remembering the Role of the Reformed Churches in the Struggle for Justice in South Africa." In Reformed Churches in South Africa and the Struggle for Justice: Remembering 1960-1990, Mary-Anne Plaatjies-Van Huffel and Robert Vosloo, 15-25. Stellenbosch: SUN Media.

Walker, Alice. 1983. In Search of My Mothers' Gardens. San Diego: Harcourt.

Walker, Alice. 1993. “In Search of Our Mothers' Gardens.” In Black Theolog: A Documentary History: Volume I 1966-1979, edited by James H. Cone, and Gayraud S. Wilmore, 339349. New York: Orbis.

Weisse, Wolfram, and Anthonissen, Carel A. 2004. Maintaining Apartheid or Promoting Change: The Role of the Dutch Reformed Church in a Phase of Increasing Conflict in South Africa. Münster: Waxmann.

Williams, Delores S. 1993. Sisters in the Wilderness: The Challenge of Womanist God-Talk. New York: Orbis.

World Council of Churches. 2020a. "WCC Mourns Passing of Rev. Prof. Dr Mary-Anne Plaatjies-Van Huffel.” News. Accessed July 29, 2020.

https://www.oikoumene.org/en/press-centre/news/wcc-mourns-passing-of-rev-prof-drmary-anne-plaatjies-van-huffel.

World Council of Churches. 2020b. Africa. Member Churches. Last modified January 1, 2006. https://www.oikoumene.org/en/member-churches/africa. 